\title{
THE MAGNIFICAT: CENTO, PSALM OR IMITATIO? ${ }^{1}$
}

\author{
Robert Simons
}

\begin{abstract}
Summary
Scholars have long noted the prominence of LXX words and themes in the Magnificat (Luke 1.46-55). Various attempts have been made to explain this prominence. Some have suggested that the Magnificat is a sort of cento, others that it is modelled upon the OT Psalms. This study will propose that it is an example of what was known in the Graeco-

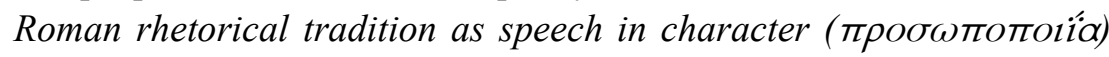
employing the technique of imitatio, and will show that many details in the text of the hymn seem to support this hypothesis.
\end{abstract}

\section{Is the Magnificat a Cento?}

Fitzmyer states, 'The heavy dependence on the Greek OT makes it evident that it [the Magnificat] is a cento-like composition, a mosaic of OT expressions drawn from the LXX.' ${ }^{2}$ Brown agrees that 'the Magnificat is almost a cento or mosaic,' confirming later, 'like the Magnificat, the Benedictus is a mosaic or cento of OT and intertestamental phrases and ideas'. ${ }^{3}$ Dirk Schinkel makes the claim that "the style device called "cento" since the time of Aristophanes

1 A Cento is a pastiche of quotes from a well-known source; imitatio refers to the imitation of a literary model. Both terms are more fully defined in the text of the article. This article is based in part on Robert C. Simons, 'Rhetoric and Luke 1-2: A Rhetorical Study of an Extended Narrative Passage' (Ph.D. dissertation, Trinity College, University of Bristol, 2006).

2 Joseph A. Fitzmyer, The Gospel According to Luke I-IX (AB 28; New York: Doubleday, 1970): 359.

3 Raymond E. Brown, The Birth of the Messiah: A Commentary on the Infancy Narratives in the Gospels of Matthew and Luke (New York: Doubleday, 1999): 357, 384. 
accounts for the form of composition of the Magnificat and is able to elucidate the unusual linguistic-formal structure of the text by Luke.' ${ }^{4}$

In order to properly evaluate these claims, it is necessary to explore what exactly is meant by a cento. The dictionary definitions of this Latin word are a 'patchwork', or a 'curtain or covering made of old garments'. 5 The literary use of the word is defined as 'a poem constructed according to strict metrical rules from a work of classical poetry, which reinterprets its subject playfully or as a parody'. ${ }^{6}$ However, Bright cautions that the cento is not an inherently parodic exercise, and is often used to treat serious subjects. ${ }^{7}$ In essence, whoever aspired to create a cento had to patch together lines or partial lines from the work of a single author (frequently Virgil or Homer) in order to create a new poem about a different subject.

Bright analysed sixteen examples of the Latin cento composed from verses in Virgil to see to what extent the practitioners of the form obeyed the rules laid down by Ausonius (one of the best-known writers of the virgilian cento). What he found was generally strict obedience especially to the first, second, and last of four rules, namely: (1) 'the juncture in a line should only occur at the places where a caesura is permitted in Virgil ...;' (2) 'If a line does not consist of a Virgilian verse reused in its entirety, it should consist of two pieces and no more;' and (4) 'the components should present the text of Virgil unchanged' ${ }^{8}$ These rules basically mean that if the Magnificat were a cento of LXX and/or intertestamental phrases and ideas, we should find each of the lines of verse in the Magnificat composed of not more than two distinct pieces of unchanged verse from the LXX, and broken only at allowable points (in other words at points where meaning and rhythm are preserved).

The examples that Schinkel offers in his article to support his contention that the Magnificat is a cento are not convincing. In the best

4 Dirk Schinkel, 'Das Magnifikat Luke 1,46-55 - ein Hymnus in Harlekinsjacke?', ZNW 90 (1999): 273-79, esp. 273 (my translation).

5 Cassell's Latin-English and English-Latin Dictionary, eds J. R. V. Marchant and Joseph F. Charles (New York: Funk \& Wagnalls, 1956), s.v. 'cento', and Oxford Latin Dictionary, eds A. Souter et al. (vol. 1; Oxford: Clarendon, 1968), s.v. 'cento'.

6 F. Kunzmann, 'Cento', Historisches Wörterbuch der Rhetorik, ed. Gert Ueding (Tübingen: Max Niemeyer, 1994): 148-52, esp. 148 (my translation).

7 David F. Bright, 'Theory and Practice in the Vergilian Cento', Illinois Classical Studies 9 (Spring 1984): 79-90, esp. 80-81.

8 Bright, 'Vergilian Cento', 84. 
cases he can only account for two or three words in a line that come unchanged from some possible LXX source, and in some cases only a part of a word that is in the Magnificat is actually present in the LXX. Brown and Fitzmyer do not try to justify their hypothesis that the Magnificat is a cento, but Brown does provide a table of possible LXX sources for the Magnificat. An examination of that table confirms that there is not even one line in the Magnificat that conforms to the rules for the composition of a cento. ${ }^{9}$ Fitzmyer, Brown, and Schinkel correctly noticed that there is a close correspondence between the words and concepts in the Magnificat and words and concepts common in the LXX, but that correspondence falls short of the kind of formal structure that is required to claim that the Magnificat is a cento.

\section{Is the Magnificat Modelled upon OT Psalms?}

Plummer states that the Magnificat 'is modelled upon the O.T. Psalms, especially the Song of Hannah (I Sam. ii.1-10)' ${ }^{10}$ He provides a table that shows line by line the relationship between the Magnificat and fourteen different LXX passages. The impression that a close study of the correspondences gives is that the Magnificat indeed contains much LXX vocabulary, many ideas commonly expressed in the LXX and conforms in general to a Septuagintal style.

Nolland finds strong support for each of three different possible answers to the question of how the Magnificat came to have its present form, one of which is that it is an adaptation of an extant psalm. ${ }^{11}$ Marshall states that 'the thought is Jewish in expression, and parallels from the OT can be easily cited,' but he goes on to say that 'we have no means of distinguishing between tradition and redaction'. ${ }^{12}$

The first hypothesis examined in this essay, that the Magnificat is a cento, obviously says too much. On the other hand, this second hypothesis, that the Magnificat is somehow modelled upon the LXX Psalms, may be saying less than what could be said. It is true that the Magnificat makes abundant use of LXX vocabulary and style, but until now the theory that it is based on OT Psalms has produced no

9 Brown, The Birth of the Messiah, 358-59.

10 Alfred Plummer, A Critical and Exegetical Commentary on the Gospel according to S. Luke (ICC; Edinburgh: T. \& T. Clark, 1905): 30-31.

11 John Nolland, Luke 1-9:20 (WBC 35a; Dallas: Word, 1989): 63.

12 I. H. Marshall, Commentary on Luke (NIGTC; Grand Rapids: Eerdmans, 1978): 79. 
consensus of scholarly opinion about the origin of the Magnificat or the part Luke played in its creation. In 1986, Zorrilla summarised the opinions of eight scholars regarding the source, style, language, and the role of Luke in the composition of the Magnificat in a table that shows almost complete lack of agreement. ${ }^{13}$ Almost a decade later, Bock offered five options for the sources of the hymn citing multiple scholars, but without drawing his own conclusion. ${ }^{14}$ The affirmation that the Magnificat is somehow modelled on the OT Psalms appears to need no defence, but it seems necessary to try to discover how it is modelled on them in order to progress any further in understanding the creation of the hymn. I propose looking at the Magnificat as an example of the rhetorical practice of speech in character (тробштотої $\alpha$ ) employing imitatio. ${ }^{15}$

\section{The Relevance of Rhetorical Techniques for a Study of the Magnificat}

Is it possible that a Hellenistic writer like Luke could have been familiar with principles set down in Latin by the likes of Quintilian, or that he could have been trained in rhetorical principles through exercises like those employed in the extant progymnasmata? ${ }^{16}$ If so, would he have employed principles from his rhetorical training and background in his writing?

13 Hugo C. Zorrilla 'The Magnificat: Song of Justice', in Conflict and Context: Hermeneutics in the Americas, ed. Mark Lau Branson and C. René Padilla (Grand Rapids: Eerdmans, 1986): 220-37, esp. 225.

14 Darrell L. Bock, Luke Volume 1: 1:1-9:50 (BECNT 3a; Grand Rapids: Baker, 1994): 142-45.

15 This develops an idea expressed by Luke Timothy Johnson, The Gospel of Luke (SP; Collegeville: The Liturgical Press, 1991): 43.

16 Progymnasmata were graded exercises from the first through to the fourth centuries AD that were designed to teach secondary students the elements of rhetorical composition. For more information about the progymnasmata and their relevance for New Testament studies, see Mikeal C. Parsons, 'Luke and the Progymnasmata: A Preliminary Investigation into the Preliminary Exercises' in Contextualizing LukeActs: Lukan Narrative and Greco-Roman Discourse, eds Todd Penner and Caroline Vander Stichele (Atlanta: SBL, 2003): 43-64; Vernon K. Robbins, 'Progymnasmatic Rhetorical Composition and Pre-Gospel Traditions: A New Approach' in The Synoptic Gospels: Source Criticism and the new Literary Criticism, ed. Camille Focant (BETL

110; Leuven: Leuven University \& Peeters, 1993): 111-47; and Kennedy, Progymnasmata. 
The fact that classical rhetoric focused on oral communication and the New Testament is written communication does not exclude the possibility that New Testament writers used rhetorical principles. First, written communication in antiquity was 'oral' in nature. Even an individual reader generally read aloud to himself, and the written documents the New Testament contains were almost certainly often read aloud to congregations. ${ }^{17}$ This has profound consequences for the interpretation of New Testament documents. In today's culture that is so oriented towards the written word and private silent reading, authors use things like bold or italic type, titles and subtitles, and placement of text to communicate extra-textual information to readers. In a culture that is oriented to hearing written texts read aloud, a whole different set of signals would be used to get the hearers' attention: prose rhythm, assonance and dissonance, accentuation (which was probably based on tone rather than on volume), use of unusual words, repetition, variation of word order and grammatical structure, and other such devices would become markers that functioned in ways similar to the visual markers we are accustomed to noting today. Many of these acoustic markers are unknown to moderns, and they become doubly difficult to detect in an unfamiliar language that is no longer spoken like koine Greek. GraecoRoman rhetoric taught these and many other principles of oral communication, and the progymnasmata provided the secondary student with practice in their effective use in written communication. ${ }^{18}$

Marrou makes it clear that the three-level Hellenistic schooling had rhetorical instruction as its goal. ${ }^{19}$ Concerning Hellenistic education, Morganthaler remarks, " "Rhetor" had a dual meaning. It referred to the teacher of the three stages [of classical education], and all those who had completed study of the three stages were "Rhetors." "Rhetor" was thus both a professional designation and an educational qualification.'

17 See Chrys C. Caragounis, The Development of Greek and the New Testament: Morphology, Syntax, Phonology, and Textual Transmission (Tübingen: Mohr Siebeck, 2004): 397-401; Samuel Byrskog, Story as History - History as Story (Tübingen: Mohr Siebeck, 2000): 116; and Josef Balogh, "Voces Paginarum”: Beiträge zur Geschichte des lauten Lesens und Schreibens', Phil. 82 (1927): 202-240, esp. 220.

18 George A. Kennedy, Classical Rhetoric and Its Christian and Secular Tradition from Ancient to Modern Times (London: Croom Helm, 1980): 5, refers to this phenomenon as 'secondary rhetoric'.

19 H. I. Marrou, A History of Education in Antiquity (London: Sheed \& Ward, 1956): 95-226 (esp. the three stages of education culminating in rhetorical instruction 142 205). See also Donald Lemen Clark, Rhetoric in Greco-Roman Education (New York: Columbia University, 1957). 
He goes on later to say, 'Education was rhetoric, and rhetoric was education.' ${ }^{20}$ Rhetoric was the basic subject upon which all higher education was founded.

Luke's level of education is illustrated by such remarks as: the Lukan preface is 'the best-written periodic sentence of the New Testament,' ${ }^{21}$ and 'Luke in the Gospel comes close to being a classical biographer, just as in Acts he comes close to being a classical historian.' ${ }^{22}$ We can be confident that Luke, as an educated person in the first century Hellenistic world, received rhetorical training as a youth.

The actual content of Luke's rhetorical training is probably reflected in the extant progymnasmata. Kennedy comments:

The curriculum described in these works, featuring a series of set exercises of increasing difficulty, was the source of facility in written and oral expression for many persons and training for speech in public life...23

In addition to such formal training, Luke would have been constantly exposed to examples of good and bad rhetoric. Graeco-Roman rhetoric profoundly influenced every facet of first-century Hellenistic life that had to do with public communication. ${ }^{24}$

Silva criticises some rhetorical analyses of Galatians because they use Latin terms in the study of a letter that was written by a Greek speaker. ${ }^{25}$ However the presence of Greek terminology, and references to Greek rhetorical and literary works in all of the Latin handbooks and rhetorical treatises, confirms that the works in Latin reflect the state of the art throughout the Empire, not just in Rome. Thus, the use of standardised Latin terms to describe rhetorical strategies and figures

20 Robert Morganthaler, Lukas und Quintilian: Rhetorik als Erzählkunst (Zürich: Gotthelf Verlag, 1993): 85, 89 (my translation). See also Philip E. Satterthwaite, 'The Background of Classical Rhetoric', The Book of Acts in Its Ancient Literary Setting I (ed. B. W. Winter and A. D. Clarke; Grand Rapids: Eerdmans, 1993): 337-74, esp. 340 .

21 Eduard Norden, Die antike Kunstprosa vom VI Jahrhundert vor Christus bis in die Zeit der Renaissance (Stuttgart: B. G. Teubner, 1958): 483 (my translation).

22 George A. Kennedy, New Testament Interpretation through Rhetorical Criticism (Chapel Hill: University of North Carolina, 1984): 108.

23 George A. Kennedy, Progymnasmata: Greek Textbooks of Prose Composition and Rhetoric (Atlanta: SBL, 2003): ix.

24 Ben Witherington, New Testament History: A Narrative Account (Grand Rapids: Baker, 2001): 240-41.

25 Moisés Silva, Explorations in Exegetical Method: Galatians as a Test Case (Grand Rapids: Baker, 1996): 93. 
does not affect the validity of the analysis of a work written in Greek. Even though the author of Luke-Acts may never have read Rhetorica ad Herennium or the later Institutio by Quintilian, what we read in these handbooks is relevant to the study of Luke-Acts because their contents reflect what he would have studied in Greek during his later years of education. Morganthaler has written a careful and comprehensive monograph comparing the teaching of Quintilian to the practice of Luke in which he concludes that the Lukan text displays countless examples of exactly those characteristics that Quintilian taught in his manual. ${ }^{26}$

\section{Speech in Character in the Rhetorical Handbooks and the Progymnasmata}

The speeches in Luke 1:5-2:52 are not technically examples of speech in character because there was no previous collection of famous speeches given by Mary, Zechariah, or Simeon upon which the speeches in Luke could be modelled. ${ }^{27}$ Nevertheless, certain of the principles of speech in character can be helpful in understanding the techniques Luke may have used to enhance the rhetorical effectiveness of the Magnificat.

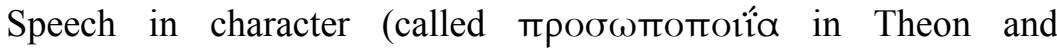
Quintilian) is 'the introduction of a person to whom words are attributed that are suitable to the speaker and have an indisputable application to the subject discussed'. ${ }^{28}$ Quintilian states that this technique can be used to '(1) display the inner thoughts of our opponents as if they were talking to themselves [soliloquy] ... (2) to introduce conversations [dialogue] ... (3) to provide appropriate characters for words of advice, reproach, complaint, praise, or pity [speeches]'. ${ }^{29}$ Hermogenes adds, 'The elaboration proceeds by three times. Begin with the present ... then run back to earlier times ... then

\footnotetext{
26 Morganthaler, Lukas und Quintilian, 41.

27 Especially after the end of the first century AD, speech in character was mostly a form of entertainment where an orator invented and delivered a speech that he judged to be typical of what a famous person would have said in a given circumstance. In earlier rhetorical theory, this figure was used in judicial and parliamentary speeches for persuasive purposes.

28 Theon Prog. 8 [Kennedy, Progymnasmata, 47].

29 Quintilian Inst. 9.2.29-31 [LCL].
} 
change to the future. ${ }^{30}$ Lausberg summarises by saying that speech in character should 'be in agreement with the character of the person speaking'. ${ }^{31}$

\section{Speeches in Classical Historiography}

Ancient historians did not have access to such resources as we have today. They relied on oral reports, interviews with eyewitnesses, and some written sources that they had to evaluate on the basis of plausibility. In addition to this liability as far as source material went, the ancient historian lived in a rhetorical-literary culture and was 'in the awkward position of serving two masters, what we call art and science'. On the one hand (especially in the best of cases like Thucydides and Polybius) he strove for accuracy, on the other, 'he must capture the reader by his art, instruct, edify, and eternalise virtue and infamy ...' ${ }^{32}$ But in spite of these two problems, it is clear that objectivity and truth were regarded as foundational principles of history writing because their absence was criticised, and abandonment of impartiality resulted in loss of reputation for the historian. ${ }^{33}$

Since their sources of information could only supply an outline of events, and as Thucydides admits, the participants in a battle have a limited and often confusing impression of what took place, ${ }^{34}$ there was a need for 'imaginative recreation and inferential elaboration from the facts'. ${ }^{35}$ This process of fusing the facts into a smooth narrative is a result of the mimetic nature of ancient historiography; that is, the attempt to create an artful portrayal of reality. However, those ancient historians who strove for truth and objectivity did attempt to narrate what actually happened in broad terms. Thus there existed a tension

30 Hermogenes 9.37-41 [LCL].

31 Heinrich Lausberg, in Handbook of Literary Rhetoric: A Foundation for Literary Study, ed. David E. Orton and R. Dean Anderson (Leiden: Brill, 1998; tr. Matthew T. Bliss): $§ 821$.

32 Charles William Fornara, The Nature of History: Historiography in Ancient Greece and Rome (Berkeley and Los Angeles: University of California, 1983): 99.

33 Examples from the time of the writing of Luke-Acts are Sallust who praised Fannius for his adherence to the truth (Hist. 1.4), and Lucian who strongly criticised several unnamed 'historians' of his time for inaccuracy and rhetorical embellishment (Hist. conscr. 29).

34 Thucydides 7.44.

35 Fornara, Nature of History, 134. 
between wanting to be faithful to the substance of the original speech and having to recreate the wording of the speech from an imperfect or incomplete memory of the event. The actual way in which different historians carried out this principle varied according to the purposes and integrity of each. ${ }^{36}$

Luke's reliability as an accurate historian, where he can be checked, speaks well for the possibility that he tried to give as accurate a report as he could of any speeches or dialogue; nevertheless, it is probable that he did not have an accurate verbatim record of what was said on most occasions where he records speeches or dialogue in the birth narratives. It is possible to envision Mary, for instance, having ' $k e p t$ all these things in her heart' (Luke 2:19, 51), telling and retelling parts of the story of Jesus' birth to members of the family and close friends, but it seems unlikely that a written record would have been made at any time soon after the events Luke narrated. Luke could have settled for simply reporting that Mary had praised the Lord for his power and faithfulness (as he did in the case of Anna in Luke 2:36-38), but instead he seems to have made use of what was the standard rhetorical procedure of his time: he composed words (or redacted written sources) to produce a speech or dialogue that was rhetorically pleasing, suitable to the speaker and listeners, coherent with his exigence and purpose, and that gave what he understood was the substance of the message. This latter option not only gives a version of what may have been said, but it also seeks to reproduce the emotion and importance of the moment.

\section{5:1 Complementary Speeches}

Two aspects of the speeches in Thucydides should be noted, as they seem particularly relevant to a study of the Magnificat. First, Immerwahr has recognised that Thucydides' speeches are 'both part of the story of the war, and complementary to it'. ${ }^{37}$ That is, the speeches are neither merely ornamental nor simple narratives of what took place, but they actually are part and parcel of what the author is trying to accomplish in his narrative. Immerwahr shows that the speeches in

\footnotetext{
36 Fornara, Nature of History, 167-68.

37 Henry R. Immerwahr, 'Pathology of Power and the Speeches in Thucydides' in The Speeches in Thucydides, ed. Philip A. Stadter (Chapel Hill: University of North Carolina, 1973): 16-31, esp. 16.
} 
Thucydides' prooemium $^{38}$ introduce the ideas of the progress and control of power as the main cause of the Peloponnesian War and suffering as a tragic theme intimately tied to the war. Additional speeches throughout the history continue to develop these two themes. Similarly, it will be shown that the Magnificat is not just an ornament or a touch of realism. Luke actually uses it to introduce and develop the reversal of expectations motif that seems to be an important part of his literary scheme.

\section{5:2 Speeches Belong to the Final Stage of Redaction}

A second relevant aspect of speeches in Thucydides is the setting of the speeches. 'The most prominent feature of the preambles and postscripts is that they are normally brief, straightforward, and factual in striking contrast to the complexity of the speeches ... Nor does Thucydides normally choose to exploit the dramatic possibilities of the situations before or after ...' ${ }^{39}$ In his examination of the setting of speeches in Thucydides, Westlake concluded that 'the inclusion of speeches may be deemed to belong to the final stage of composition'. ${ }^{40}$ This does not necessarily indicate that they are an afterthought or that they come from some source that was inserted unmodified into a foreign context. Today, the introduction is often the last thing written for a book or essay. This does not mean that it is an afterthought; rather it is such an important part of the whole written work that it virtually must be written last so that it can accurately reflect the nuances of purpose and development in the rest of the nearly finished work. This seems also to have been the case for speeches in rhetorical historiographic writing. Scholars have commented on the fact that the Magnificat can be removed from its place in the Lukan birth narratives without creating a disruption to the flow of the narrative. ${ }^{41}$ This may indicate that Luke, like Thucydides, left the redaction and inclusion of speeches until the end of the writing process.

\footnotetext{
38 Thucydides introduction is twenty-three chapters long and generally could be said to correspond to the Lukan birth narratives, in that it provides a narrative introduction to events that precede the main subject of the history, which is the Peloponnesian War in the case of Thucydides.

39 H. D. Westlake, 'The Settings of Thucydidean Speeches' in The Speeches in Thucydides, ed. Philip A. Stadter (Chapel Hill: University of North Carolina, 1973): 90-108, esp. 91.

40 Westlake, 'Thucydidean Speeches', 103.

41 For example, see C. F. Evans, Saint Luke (Philadelphia: Trinity, 1990): 171.
} 


\section{Imitatio in Graeco-Roman Rhetoric and Historiography}

Quintilian speaks about the practice of imitatio in his tenth book, ${ }^{42}$ where he elucidates several principles that are designed to guide in the process. The gist of these principles is that merely to imitate words, phrases, rhythms, and the like in a slavish manner produces a work that is dull and lifeless. The student must first understand what is admirable in what he is imitating, then use words, phrases, rhythm and the like in a way which also 'adds his own good qualities to these, making good the deficiencies and cutting out any superfluities'. ${ }^{43}$ What Quintilian is describing here is a creative process that builds in an original way upon what is already recognised to be admirable. This closely corresponds to Nolland's observation that the Magnificat 'is at times marked by OT allusions, but more commonly OT motifs and language are used in a fresh coinage which evokes more generally the whole thought world of OT faith'. ${ }^{44}$

The bulk of the exercises contained in the progymnasmata are also based on this principle of rhetorical imitation. Students would be taught to rewrite, expand, abbreviate, or otherwise transform a fable, chreia, maxim, or narrative that was well-known and admired so that the result would be a new creative work that was still recognisably modelled upon the original. These exercises were designed so that the student would become accustomed to understand what was admirable in a speech or piece of writing, and then be able to use that, adapt it to a new situation, and improve on it.

\section{A Rhetorical Analysis of the Magnificat}

What follows is a study of the Magnificat that is based on the hypothesis that it is an example of speech in character using the rhetorical principle of imitatio. The plausibility of the hypothesis can be tested by seeing how well it explains the textual features of the poem, its structure, and the way it fits into the rest of Luke-Acts. The reader is encouraged to refer to a layout of the Magnificat on the last

42 Quintilian Inst. 10.2.1-3.

43 Quintilian Inst. 10.2.28 [LCL].

44 Nolland, Luke, 74. 
page as the discussion proceeds. The numbers at the left are not attempts to delineate 'lines' of poetry, rather they are to facilitate the discussion with a reference system other than verse numbers, as these seem not to correspond well to the way the poem is organised.

\section{7:1 First Section}

In the layout, the hymn is divided into several sections according to the topic treated. The first section contains Mary's words about herself (note the five uses of the first person singular pronoun within just a few words). ${ }^{45}$ Many commentators have noticed that in this part of the hymn Mary talks about herself, but none have noticed that the sequence of time exactly follows the suggestion of Hermogenes (see the text referred to by fn. 29) to start in the present (\#1, Mary says what she is doing), go to the past (\#2, two aorist verbs, the second of which surely refers to past time), and continue to the future (\#3, Mary says what others will say about her as a result of God's action). This sequence of verb tenses did not come from passages cited from the LXX. The different verses that Brown and Plummer have suggested as possible sources of inspiration for this part of the hymn do not have this sequence of times. ${ }^{46}$ Here we have tentative confirmation that Luke may have intentionally redacted this hymn according to accepted rhetorical principles.

\section{7:2 Second Section}

In the second section of the hymn (\#4 and 5), Mary begins to talk about what God is like. Line \#4 (Holy the name of him) seems to stand alone (against Mínguez who thinks that this line is a smooth transition from Mary talking about herself to Mary talking about God). ${ }^{47}$ It is set off by a preceding and following kai that breaks the flow of the hymn. The verbless affirmation does not relate directly either to the actions of God

45 Josef Ernst, Das Evangelium nach Lukas (RNT; Paderborn: Friedrich Pustet Regensburg, 1976): 85.

46 Brown, The Birth of Messiah, 358-59; Plummer, Luke, 30-31. For example, in 1 Sam. 2:1 (LXX), Hannah uses the aorist passive, while Mary in the analogous Luke 1:46 uses the present. An investigation of other examples from the LXX show that whether Luke composed or redacted this section, the sequence of tenses he chose did not come from any combination of LXX verses he might have had in mind as an inspiration.

47 Dionisio Mínguez, 'Poética Generativa del Magnificat', Bib 61 (1980): 55-77, esp. 59. 
described previously (he looked upon Mary's humble state, and he did great things), nor does it relate directly to the following affirmation (his mercy to generations and generations of those fearing him). ${ }^{48}$ Rather than a transition, it appears more like an abrupt irruption of praise that signals the end of Mary's meditations about herself and the beginning of her affirmations about God. It is only transitional in the sense that the following phrase (\#5) is also verbless, expressing that aspect of God's holiness (mercy) that will be explored in the rest of the hymn. If we were to outline phrases four, five, and six according to content, the outline might look like this:

I. God possesses the attribute of holiness

A. One aspect of that attribute is mercy

1. That mercy is shown in mighty works such as
a. scattering the proud
b. casting down the mighty
c. exalting the humble
d....

In other words, the abrupt change signalled by phrase \#4 marks the beginning of a highly structured part of the hymn. ${ }^{49}$

\section{7:3 Third Section}

In order to appreciate Luke's rhetorical artistry, we need to examine this structure. Phrase \#5 corresponds closely to \#13, the last phrase. Both speak of God's mercy, both say to whom and until when that mercy will be shown in an inverted chiastic order. Phrase \#6 is a general introduction to the following six phrases because it leads the listener to expect examples of God's mighty works. Phrases \#7-\#12 follow a chiastic pattern that could be described as $\mathrm{A} \mathrm{BB}^{\prime} \mathrm{C}^{\prime} \mathrm{C} \mathrm{A}^{\prime}$ (where ' indicates an act of God on behalf of his people, and the absence of the ' indicates an act of God against his enemies). Luke uses three different ways of showing the listener what lines are to be associated with what other lines: grammatical structure, prose rhythm,

48 Against Herman Hendrickx, The Third Gospel for the Third World, Volume One: Preface and Infancy Narrative (Luke 1:1-2:52) (Quezon City: Claretian, 1996): 126.

49 Joel B. Green, The Gospel of Luke (NICNT; Grand Rapids: Eerdmans, 1997): 99, shows some of the parallelism contained in these verses. 
and content. In our analysis of the Magnificat, we will consider each of these three ways for each pair of lines.

Tannehill makes a start at analysing the rhythm and rhetorical structure of the Magnificat, but stops short of actually scanning the lines for prose rhythm. Drake picks up on Tannehill's work, and mentions certain aspects of rhythm and rhetorical strategy in the Magnificat, but once again fails to follow through with a complete analysis of the poem. ${ }^{50}$ Please note that prose rhythm (Latin numeros) does not refer to poetic meter, but to counting long syllables as two beats (spatio temporum) and short syllables as one. ${ }^{51}$

Phrases \#7 and \#12 have similar grammatical structure: the aorist verb $^{52}$ is first with the implied subject being God, and a direct object is second. The rhythm of the starting words of each of these two phrases is identical (and very unusual). Both are made up of no less than five short syllables, ${ }^{53}$ and both are followed by two more short syllables before there is finally a break with a long syllable (a total of seven short syllables at the beginning of each line). ${ }^{54}$ Quintilian and Dionysius of Halicarnassus both counsel against such a long succession of short syllables. ${ }^{55}$ The 'jerky' effect of these seven short syllables

50 Robert C. Tannehill, 'The Magnificat as Poem', JBL 93 (1974): 263-75; Larry Keith Drake, 'The Reversal Theme in Luke's Gospel' (Ph.D dissertation, Saint Louis University, 1985): 124-27

51 Philomen Probert, A New Short Guide to the Accentuation of Ancient Greek (London: Bristol Classical Press, 2004): 23-39 gives rules for determining the length of vowels. Hardy Hansen and Gerald M. Quinn, Greek: An Intensive Course (2nd edn; New York: Fordham University, 1992), which is a grammar of classical Greek, specifies vowel lengths in morphemes. And Henry George Liddell and Robert Scott, $A$ Greek-English Lexicon (Oxford: Clarendon, 1983) note the length of vowels in doubtful cases. Refer to Simons, 'Rhetoric and Luke 1-2', 229-30 for a fuller explanation of scanning Greek prose rhythm.

52 The aorist here is probably neutral with reference to time, referring rather to characteristic or so-called 'gnomic' acts of God. See Daniel B. Wallace, Greek Grammar: Beyond the Basics (Grand Rapids: Zondervan, 1996): 562; Robert C. Tannehill, Luke ANTC (Nashville: Abingdon, 1996): 55-56. The aorist tense and implied subject is the same for all six phrases in this section, although the position of the verb varies.

53 Heinz Schürmann, Das Lukasevangelium erster Teil: Commentar zu Kap. 1,1-9,50 (HTKNT; Freiburg: Herder, 1969): 70, noticed this rhythmic anomaly but did not comment on what significance it might have.

54 Note that the $1 \varepsilon$ in $\delta 1 \varepsilon \sigma k o ́ p \pi r \sigma \varepsilon v$ is not a diphthong, but two separate short

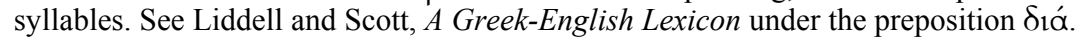

55 According to Dionysius (Comp. 17), these words would be made up of the combination of two feet, the hegemon or pyrrhic (two shorts for the prepositional prefix) which he calls neither impressive nor solemn, and the choree (three shorts) which is 'a mean foot lacking in dignity and nobility, and nothing noble could be made 
would certainly have made an impression on listeners who were aware of such things, and that is probably exactly what Luke wanted. The attention-getting interruption of phrase \#4 has faded, and this new attention-getting rhythm signals the beginning (and later the ending) of the six characteristic acts of God that Luke wants his readers to notice. Phrases \#7 and \#12 also have parallel but contrasting content. God 'scatters the proud' but 'helps Israel'. Here, Israel represents 'those who fear him' (\#5) and 'Abraham and his seed' (\#13); the proud are obviously neither. This is the first pair of antithetical parallel ideas. The order here is: (1) a characteristic act of God against his enemies, then (2) a characteristic act of God for his people.

This order of antithetical parallel acts (first against enemies, then for God's people) is preserved in the second pair of acts (phrases \#8 and \#9), as is the grammatical structure (verb, object). When Luke changes the order of the parallel ideas, putting an act for God's people first and then against God's enemies second (in phrases \#10 and \#11), he also reverses the grammatical structure in both phrases, putting the object first and the verb second.

Having mentioned the grammatical structure of the next two pairs in relationship with their content, note that both phrase \#8 and \#9 begin with the same rhythmic structure: short, long, short. Dionysius calls this rhythm the amphibrach, and characterises it as 'enervated ...effeminate and ignoble'. ${ }^{56}$ Once again Luke has chosen to use something that would call the attention of listeners by sort of grating on their sensibilities. The repetition of this rhythm at the beginning of two successive lines would reinforce the idea that they should be taken together. Notice that in phrases \#7 and \#8, Luke employs a majority of short syllables, increasing the grating jerky effect when read aloud. Notice also that there is no conjunction joining phrase \#7 to \#8, but a continuation without break. In contrast, in phrase \#9, Luke employs a majority of long syllables, producing a more peaceful, contemplative sound after all the short syllables of phrases \#7 and \#8. This probably is associated with the fact that Phrase \#9 introduces the first act of God in favour of his people. Luke would want to slow down the reading at this point, and lead the listener to reflect on and take pleasure in the

out of it'. Quintilian advises the avoidance of 'the jerky effect of a run of short syllables' (Inst. 9.4.67), and later repeats that in a continuous series, short syllables have 'a jerky effect' (9.4.92).

56 Dionysius of Halicarnassus, Comp. 17. 
change in content. A visual representation of what it might have sounded like follows:

God scatters the proud in the thoughts of their hearts throws the powerful down from their thrones

$$
\begin{aligned}
& \text { and } \\
& \text { e } x \text { a } 1 \mathrm{t} s \mathrm{~s} h \mathrm{e} 1 \mathrm{o} w \mathrm{y}
\end{aligned}
$$

Phrases \#10 and \#11, as already mentioned, have the grammatical structure (object then verb) and the order of antithetical parallel content (act for God's people then act against God's enemies) reversed with respect to the previous two pairs considered. In addition, both phrases have an adjectival modifier. Once again, both phrases begin with words that have identical rhythmic structure: this time two long syllables followed by a short. Dionysius calls this foot a bacchius, and refers to it as 'virile and appropriate for solemn language'. ${ }^{57}$ By now Luke's listeners probably would have been expecting the parallel rhythmic structure. The more 'acceptable' structure he chose would have been a pleasing respite to their ears and would have continued the more solemn and contemplative mood established by the rhythm of the preceding phrase \#9. In contrast, the return to the jerky seven short syllables at the beginning of phrase \#12 would have made it more probable that his listeners would have made the connection with the first phrase (\#7) of this series of God's characteristic acts.

\section{7:4 Final Section}

The final phrase \#13, as already mentioned is parallel in content to phrase \#5. The repetition of the word ' $€$ $\lambda$ EO emphasises the parallelism. The corresponding phrases that indicate until when and to whom God's mercy is shown are in an inverted order. Phrase \#13 has an additional statement that has nothing corresponding to it in phrase \#5: $k \alpha \theta \dot{\omega} s$

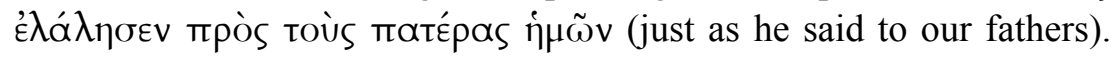
This statement expresses explicitly what Luke shows implicitly throughout the birth narratives by his use of LXX style and wording and by telling the story of Jesus' birth in a way that evokes the memory of similar series of events that God had brought about in the OT past: God is faithfully fulfilling what he promised to do long ago through the events that Luke is recording for us.

57 Dionysius of Halicarnassus, Comp. 17. 
Overall, these intricate structural details at the level of grammar, content, and rhythm are truly remarkable. It seems highly unlikely that all this occurred by chance, especially given that the rhetorical handbooks and literary criticism of Luke's time did take note of such things. We are led to believe either that Luke is the one responsible for having chosen the words, and the one who carefully put them in this order to express exactly these thoughts, or he recognised the rhetorical merit of an already existing hymn and included it at this point because it complemented his narrative so well.

\section{How the Magnificat Fits into the Rest of Luke-Acts}

Phrases \#1-\#3 are connected to the annunciation of Jesus' birth and Mary's meeting with Elizabeth through content and word repetition. ${ }^{58}$ The idea of the holiness of God or of his name as expressed in phrase \#4 stands alone. It is not an idea that is explicitly repeated in Luke. The idea of God's mercy (expressed in phrases \#5 and \#13) is repeated in the episode of John's birth (1:58) and twice in the Benedictus (1:72, 78 ), but is only mentioned once in the rest of Luke-Acts (Luke 6:36 using a different word).

The basic idea expressed by the set of phrases \#7-\#12, however, is to portray certain characteristic acts of God both against his enemies and for his people as part of the motif of reversal of expectations which Luke introduces here: the arrogant, the mighty, and the rich suffer loss while the humble, the hungry, and Israel (God's servant) receive appropriate blessings. In the Magnificat, this motif is associated with God fulfilling his promises (Luke 1:55). The fact that Mary spoke these things in the context of her pregnancy, would lead Luke's listener to expect that the child who will be born will be instrumental in carrying out these acts and fulfilling God's promises. In fact the motif of reversal of expectations is developed throughout the rest of Luke-Acts in precisely this way. ${ }^{59}$

The passage from Isaiah that Jesus read at Nazareth in Luke 4:18 promises that he will minister to the poor and oppressed. The blessings and woes he pronounced in the sermon on the plain (6:20-26) reinforce the reversal of expectations motif of the Magnificat. In the story about

58 See Green, The Gospel of Luke, 98.

59 Robert H. Stein, Luke NAC 24 (Nashville: Broadman, 1992), 96. 
Jesus sharing a meal in the house of Simon the Pharisee in 7:36-50, a despised woman is exalted, and Simon, the arrogant Pharisee is debased by Jesus' words and actions. Luke 9:10-17 narrates a time when the hungry are literally fed by Jesus' disciples at his express command. Luke 10:18 speaks of Satan falling from heaven apparently as a result of the ministry of Jesus and his authorised disciples. The rich fool (12:13-21), the rich man in the parable about Lazarus (16:19-31), and the rich young ruler (18:18-30) all went away empty in some form or another, while the poor and despised enjoyed the banquet (14:1524), and Lazarus is consoled in the bosom of Abraham (16:19-31). In all these stories about Jesus, he actually does and promotes what the Magnificat claims are characteristic acts of God. In this way Luke makes some very controversial words and works of Jesus reinforce the idea that he is actually doing what God characteristically does. The conclusion: Jesus is God's Son.

In Acts, the arrogant rulers are regularly made fools of by the unlettered disciples of Jesus (Acts 4:5-22; 5:17-42; 12:6-18). Herod is thrown down from his throne by a horrible death (12:20-25). Paul gets the better of high Roman officials (16:16-40; 22:22-29). These and other narrated events show that what the Magnificat affirms and that which God characteristically does is also done by followers of Jesus who are empowered by his Holy Spirit.

The need to create a speech that is suitable for the speaker and the situation is a major point in the progymnasmata and the rhetorical handbooks. First let us focus on Mary, the speaker. What we know of her before the hymn is limited. In 1:29, she was troubled by the angel's greeting, in 1:34 she asked how her imminent conception could occur, in 1:38 she submitted to God's will. After hearing about Elizabeth's conception Mary hurried to see her, and following the Spirit-inspired greeting there, spoke the words of the Magnificat. After the hymn, in 2:7 she gave birth to Jesus. We are told twice that she kept all that was being said and done in her heart $(2: 19,51)$. She marvelled at Simeon's words (2:33) and could not understand why her son acted as he did in the episode when he was twelve years old (2:48).

Is the Magnificat something that a person like Mary would speak? Admittedly, Mary would not have been capable of creating anything like the complex correspondences of Greek rhythm and word order that are evident in the Magnificat. Luke or some other redactor familiar with the canons of Graeco-Roman rhetoric imposed all that on the 
content. However, notice that the basic style is paratactic: clauses connected by coordinating conjunctions - just like most OT narrative and poetic passages. The words are mostly taken right out of the OT. And the acts of God which are listed might be those that would linger in the mind of a young woman from a humble background in a patriarchal society under foreign domination who is innocently pregnant out of wedlock: for they are acts which speak of hope for the oppressed and downtrodden of this world. Overall, as far as content and wording go, this hymn might easily represent the very thoughts Mary had as she 'treasured up all these things and pondered them in her heart' (2:19). ${ }^{60}$ Whether Luke imported a source or redacted traditional material in rhetorical way, the content (if not the form) of the Magnificat is something that Mary could plausibly have spoken. The Magnificat is also suitable to the situation of the annunciation of the birth of the one who will bring fulfilment to God's promises. It is a hymn of praise that names characteristic acts of God against his enemies and in favour of his people, similar in many ways to OT models.

At this point we can say with some confidence that statements like those of Brown, Farris, and Hendrickx, ${ }^{61}$ that treat the Magnificat as a slightly irrelevant hymn that Luke adapted rather poorly to its immediate context, need to be rethought. The Magnificat is a rhetorical masterpiece with a complex internal structure. It relates naturally to the near context of the birth narratives with the more distant context of the body of Luke-Acts, and develops the reversal of expectations motif introduced by the Magnificat. It is not only a beautiful hymn of praise and a great encouragement to the humble, poor and powerless who fear God; it is also an integral part of Luke's persuasive enterprise, designed to help listeners to align themselves with Luke's conception of Jesus' identity and significance. Luke appears to have achieved all of this at

60 Bock, Luke, 145.

61 For example, Brown, The Birth of Messiah, 348, says that the Magnificat and Benedictus 'do not relate to those characters [Mary and Zechariah] in a specific way'. And 'there are lines in the canticles that are awkward when applied to the situation of the speakers'. Stephen Farris, The Hymns of Luke's Infancy Narratives: Their Origin, Meaning and Significance (JSNTSup; Sheffield: Sheffield Academic, 1985): 26, 'the praise of God in the Magnificat is general rather than specific in its content, making very little reference to its narrative context'. And Hendrickx, The Third Gospel for the Third World, 115, 'The songs in the infancy narratives ... fit somewhat loosely into the context ...'. 
least in part through the use of certain rhetorical tools such as variation of grammatical structure and prose rhythm (variatio).

\section{Concluding Reflections}

Although the Magnificat clearly is not a cento created from LXX source material, it clearly is modelled on ideas and words found in the LXX. This suggests that Luke may have been following the practice of imitatio referred to by Quintilian and taught in the progymnasmata. A detailed examination of the text revealed the following features that also suggest Luke was following Graeco-Roman rhetorical principles when he redacted the Magnificat:

1. The time sequence in the first section of the hymn follows what Hermogenes suggested for speech in character (present, past, future). This time sequence is different from that in possible LXX sources.

2. Those paired phrases of the poem expressing antithetical parallel content were composed using identical prose rhythm at the beginning of both phrases in each pair and identical grammatical structure for the paired phrases. This was sustained throughout the six phrases in the whole middle section that expounds God's characteristic acts against his enemies and for his people.

3. That middle section of the poem introduces the reversal of expectations motif that carries through the rest of Luke and Acts, just as speeches in Thucydides often introduce ideas that are important throughout his historical work.

4. In accordance with rhetorical practice, the content of the Magnificat is appropriate to the speaker and the situation.

5. The observation that speeches in Thucydides seem to belong to the final part of the writing process may explain why the Magnificat could be removed from the Lukan narrative without producing a textual discontinuity.

Taken all together, it seems possible that Luke's intention was to create a poem of praise and celebration that was both a new artistic creation, and also strongly tied to LXX roots: a speech that employed some sophisticated Graeco-Roman rhetorical techniques, and also one that would call to the minds of his hearers the piety and devotion of the

Greek OT. This strongly suggests that the Magnificat is an example of imitatio. Luke may have faced the choice of whether simply to state 
that Mary spoke words of praise and worship on that occasion, or to attempt to artistically recreate the scene in a way that captured its high emotion and transcendent spiritual significance. He chose the latter. Whether Luke had a written source to work from, or simply knowledge that Mary spoke words of praise and celebration during her visit to Elizabeth's home, it seems fairly clear that he is responsible for the present form of the Magnificat. 


\section{The Magnificat}

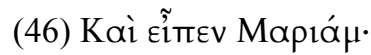

\section{Mary's words about herself (what God has done).}

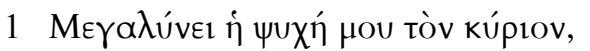

[Present]

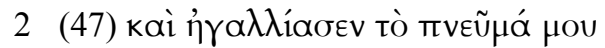

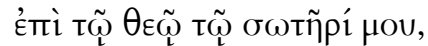

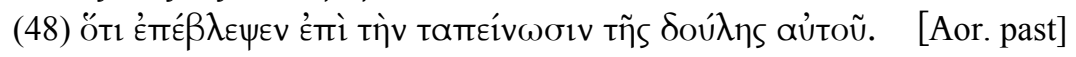

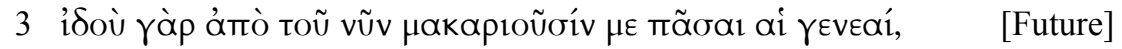

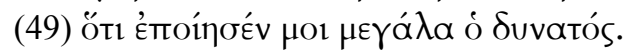

Mary's words about God (what he is like).

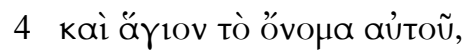

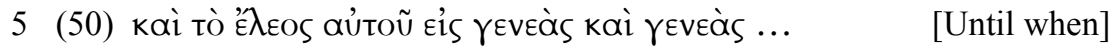

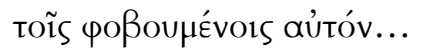

Mary's words about God (what he does).

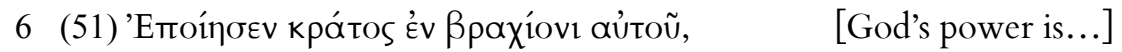

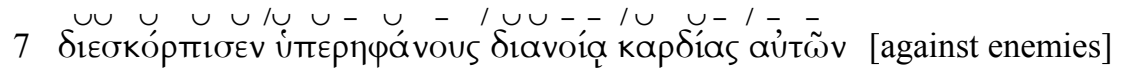

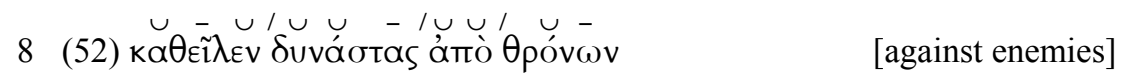

9 каì ü

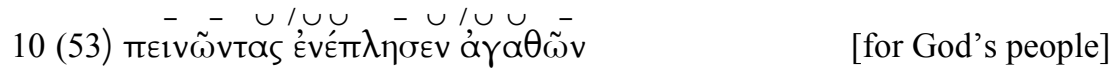

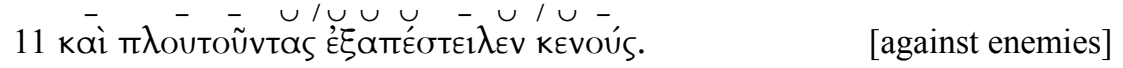

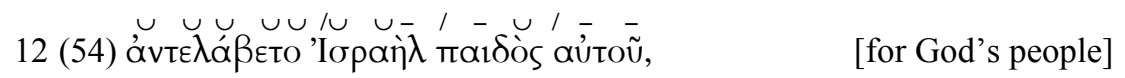

Mary's words about God (what he is like).

$13 \mu v \eta \sigma \theta \tilde{\eta} v a 1$ É $\lambda \dot{o}$ ous,

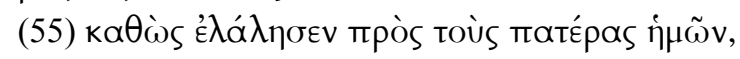

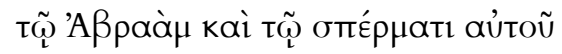

[To whom] Eis tòv aî̃va.

[Until when]

Numbers at the extreme left are to aid in the discussion. Numbers in parenthesis are verses. ' $U$ ' represents a short syllable, '-' represents a long syllable. Comments in brackets call attention to parallelism of thought. 